\title{
Неінвазивні методи діагностики в плануванні реконструктивних втручань на кінцівках складними комплексами тканин
}

\begin{abstract}
Мета роботи: дослідити ефективність методу ультразвукового дуплексного сканування в плануванні реконструктивних втручань при дефектах покривних тканин кінцівок складними комплексами тканин.

Матеріали і методи. У роботі проаналізовано дані 50 хворих, яким у передопераційному періоді з метою вибору об’єму оперативного втручання виконували ультразвукове дуплексне сканування (УЗДС). До задач дослідження гемодинаміки кінцівки входило підтвердження прохідності судин та ступінь їх функціонування. Окрім того, УЗДС використовували для дослідження регіонарної гемодинаміки у зоні ранового дефекту та у донорській ділянці майбутнього складного клаптя.

Результати досліджень та їх обговорення. В I групі (n = 15) хворим із надвеликою (понад 1 \% площі) рановою поверхнею й пошкодженням м'яких тканин нижче глибокої фасції після детальної передопераційної підготовки та дослідження гемодинаміки ділянки пошкодження виконано 25 (20,2 \%) відновних операцій ДПТ. II група (n = 13) складалася з постраждалих із ДПТ, які виникли разом або внаслідок пошкодження кістково-суглобового апарату - 42 (33,9 \%) втручань. III група (n = 22) хворих із поєднаною чи множинною травмою, що супроводжувалася пошкодженням магістральних судин, нервів, частковим або повним відокремленням кінцівки. В цій групі виконано 57 (45,9%) реконструкцій ДПТ.
\end{abstract}

Ключові слова: клапоть; ультразвукове дуплексне сканування; реконструктивні втручання; ділянка пошкодження; кінцівки.

Постановка проблеми і аналіз останніх досліджень та публікацій. Дослідження кровообігу в травмованій кінцівці дозволяє оцінити компенсаторні можливості організму та вплив порушеної регіонарної гемодинаміки на репаративні процеси $[1,4]$.

Відомості про анатомо-функціональні та гемодинамічні особливості в ділянці реконструкції при планових операціях роблять можливим успішне виконання складних втручань, але при розтрощенні тканин й значному інфікуванні можливий розвиток як запальних ускладнень, так й формування некрозів клаптів [2, 3, 8].

Важлим $є$ використання неінвазивного методу діагностики регіонарної гемодинаміки, який дозволяє отримати достовірну інформацію в короткі строки та без додаткових пошкоджень пацієнта. Таким потребам відповідає ультразвукове дуплексне сканування з кольоровим картуванням [5, $6,7]$.

Мета роботи: дослідити ефективність методу ультразвукового дуплексного сканування в плануванні реконструктивних втручань при дефектах покривних тканин кінцівок складними комплексами тканин.

Матеріали і методи. У роботі проаналізовано дані про 50 хворих із рановими дефектами покривних тканин (ДПТ) кінцівок, яким у передопераційному періоді з метою вибору об'єму оперативного втручання виконували ультразвукове дуплексне сканування (УЗДС) із кольоровим кар- туванням судин травмованої кінцівки. Серед обстежених чоловіків - 49, жінок - 11. Середній вік $(39,9 \pm 4,3)$ року.

Дослідження виконували на апараті «Vivid 3 Expert» фірми “General Elektric” (США) з використанням лінійного датчику з діапазоном частот $5-10$ МГц.

До задач дослідження магістральних судин входило підтвердження прохідності поверхневих та глибоких вен на всьому протязі, виявлення функціональної недостатності венозних клапанів, отримання характеристики просвіту судини та його стінки, визначення патологічних вено-венозних рефлюксів. При дослідженні артеріального кровообігу оцінювали прохідність судин на всьому протязі, товщину та цілісність стінки, максимальну лінійну швидкість кровотоку (ЛШКтах), кінцеву (мінімальну) швидкість кровотоку (ЛШКтіn) та резистивний індекс (РI), при необхідності - ділянку реконструйованої артерії. Обов’язково вивчали м'які тканини у ділянці пошкодження для виявлення патологічних утворень (гематом, сером тощо).

Окрім того, методику ультразвукового дуплексного сканування використовували для дослідження регіонарної гемодинаміки у зоні ранового дефекту та у донорській ділянці майбутнього складного клаптя. Під контролем датчика визначали довжину та ширину ніжки й клаптя, його напрямок. Також оцінювали характеристики живильної артерії - іï внутрішній діаметр, лінійну швидкість кровообігу, наявність колатеральних гілок, анастомозів та перфорантів. 
Пацієнтам було виконано 124 операції з приводу відновлення пошкоджених тканин. Усі хвоpi були розподілені на 3 групи залежно від розмірів, глибини та ступеня пошкодження м'яких тканин та інших структур кінцівок. I група - 15 (30 \%) пацієнтів з надвеликою (понад 1 \% площі) рановою поверхнею й пошкодженням м'яких тканин нижче глибокої фасції. В цій групі виконано 25 (20,2%) відновних операцій. II група складалася з 13 (26 \%) постраждалих з ДПТ, які виникли разом або внаслідок пошкодження кістково-суглобового апарату - 42 (33,9 \%) втручань. III група - 22 (44 \%) хворих із поєднаною чи множинною травмою, що супроводжувалася пошкодженням магістральних судин, нервів, частковим або повним відокремленням кінцівки. В цій групі виконано 57 (45,9%) реконструкцій ДПТ.

Результати досліджень та їх обговорення. Безперечно, виконання повноцінних реконструкцій складними комплексами тканин - пріоритетна задача при відновленні форми та функції травмованих кінцівок, але об’єм та ступінь пошкодження тканин це не завжди дозволяє. Ми вважаємо, що метод УЗДС дозволяє об'єктивно оцінити гемодинаміку травмованої ділянки та обрати найбільш доцільний спосіб закриття ранової поверхні з метою запобігання післяопераційним ускладненням (некрозів, ішемії клаптів тощо).

Так, в I групі $(\mathrm{n}=15)$ хворим із надвеликою (понад 1 \% площі) рановою поверхнею й пошкодженням м'яких тканин нижче глибокої фасції після детальної передопераційної підготовки та дослідження гемодинаміки ділянки пошкодження виконано 25 (20,2 \%) відновних операцій ДПТ.

У 3 хворих, за даними УЗДС, показники макрогемодинаміки наближалися до норми (реєструвався ламінарний кровоток з дво-трифазним спектром, PI $=1,07 \pm 0,3,(\mathrm{p} \leq 0,05))$ при площі рани $1 \%$ й більше, тому недоцільним було використання складних комплексів тканин. Для закриття ранової поверхні використовували пластику розщепленим шкірним трансплантатом товщиною 0,25-0,3 мм.

У 12 пацієнтам, за даними УЗДС, пошкоджень магістральних артерій та вен кінцівок не виявлено. Відсутність ішемії кінцівок, венозних тромбозів, як наслідок задовільної регіональної гемодинаміки в зоні пошкодження, у 8 випадках сприяли виконанню пластики дефекту ковзкими плоскими клаптями з близьких до дефекту тканин, в одному випадку - мостоподібним клаптем на 2 живильні ніжках, в одному випадку - ротаційним клаптем на одній живильній ніжці.
У пацієнта 3 некрозом ділянки п'яти закриття дефекту виконано суральним шкірно-фасціальним клаптем. За даними УЗДС, живильну ніжку складала мала підшкірна вена (МПВ) 3 мм в діаметрі, прохідна на всьому протязі та 5 артеріальних перфорантів між гомілковими судинами в ділянці реконструкції. В 1 випадку за даними сканування реєстрували зниження ЛШК max по глибокій стегновій артерії (ГСА) $(40 \pm 5,0 \mathrm{~cm} / \mathrm{c},(\mathrm{P} \leq 0,05))$ 3 розщепленням систолічного піку спектра, що свідчило про вазоспазм і пошкодження дистальних гілок ГСА, тому використали пластику дефекту плоским ковзким клаптем із використанням тканинного експандера об'ємом 400 мл в 2 етапи. В одному випадку напівциркулярного дефекту передпліччя найбільш оптимальним для відновлення форми та функції кінцівки було використання трубчатого шкірно-жирового клаптя на передній черевній стінці - 3 етапи реконструкції.

У 6 випадках донорські ділянки та остаткові рани закривали розщепленими автодермотрансплантатами. Післяопераційних ускладнень серед хворих даної групи не було.

У постраждалих II групи (n = 13) ДПТ виникли разом або внаслідок пошкодження кістково-суглобового апарату й супроводжувалися значним пошкодженням шкіри, м'язів, сухожилків та ін.

При УЗДС у 2 хворих виявлено оклюзивні тромбози глибоких вен травмованої кінцівки, тому використання складних комплексів тканин було недоцільним у зв'язку з великим ризиком тромбоемболічних ускладнень у післяопераційному періоді. У 3 пацієнтів площа рани перевищувала 1 \% поверхні. Отже, методом вибору оперативного втручання у цих хворих була пластика дефекту вільним шкірним розщепленим трансплантатом (9 втручань).

Відсутність патологічних змін у магістральних артеріях і венах, за даними УЗДС, у 3 випадках дозволило виконати 3 пластики ДПТ ковзкими плоскими клаптями, одним ротаційним шкірно-фасціальним клаптем на живильній ніжці, 1 суральним шкірно-фаціальним клаптем (4 діючі перфоранти між великогомілковою та суральною артеріями в зоні реконструкції, МПВ представлена єдиним стовбуром, діаметр 3,8 мм).

У 2 хворих з частковою ампутацією дистальних відділів стопи спостерігали зниження ЛШК max дистального відділу задньої великогомілкової артерії (ЗВГА) до $30 \mathrm{~cm} / \mathrm{c}$ і також зниження ЛШК max дистального відділу передньої великогомілкової артерії (ПВГА) до 35 см/с. Для відновлення форми й функції кінцівки використовували шкірно-жирові трубчаті клапті з віддалених діля- 
нок із міграцією в одному випадку в 9 етапів, в одному випадку 4 етапи реконструкції.

В одного хворого з тривало існуючим ДПТ на передній поверхні гомілки за умов “сліпої” ділянки кровопостачання також доцільне використання трубчатого шкірно-жирового клаптя (6 етапів).

У 9 випадках донорські ділянки та остаткові рани закривали розщепленими автодермотрансплантатами. Післяопераційних ускладнень серед хворих даної групи не було.

Найтяжчі ушкодження тканин спостерігали у хворих III групи $(\mathrm{n}=22)$. Поєднана чи множинна травма кінцівок, що супроводжувалася пошкодженням магістральних судин, нервів, частковим або повним відокремленням кінцівки. Пріоритетним завданням у цій групі було збереження життя та кінцівки, по можливості з максимальним відновленням іï функції, тому вибір методу закриття ранового дефекту на основі лише клінічних даних був складним.

У випадках травмування судин в ургентному порядку одному хворому виконано протезування автовеною загальної стегнової артерії (ЗСА), 2 хворим - автовенозне протезування підколінної артерії (ПКА), в 4 випадках виконано ревізію судинно-нервово пучка (СНП), в 1 - додатковою тромбектомією. У зв'язку з неможливістю зберегти 4 хворим виконано ампутацію кінцівки.

Усім пацієнтам у зв'язку з початково порушеним кровообігом у кінцівках, надвеликим ризиком некрозів та ішемії складних клаптів, ранові поверхні закривали вільними розщепленими автодермотрансплантатами (12 втручань).

Лише в одному випадку травматичного відокремлення кінцівки на рівні верхньої третини для формування кукси під протез використано комбіновану пластику - поєднання переміщеного мостоподібного клаптя з закриттям донорської ділянки розщепленим автодермотрансплантатом.

У 6 пацієнтів із пошкодженням периферичних судин і нервів кінцівок (при дуплексном скануванні у всіх випадках реєстрували посилення ЛШК по ПВГА та ЗВГА зі зниженням РI до 0,9 \pm 0,25 (р $\leq 0,05$ ), формуванням монофазного спектра як ознаки функціональної вазодилатації внаслідок місцевих факторів (гіпоксії, тканинного катаболізму)), надвеликими рановими поверхнями (понад 1 \% площі) виконували пластику вільними шкірними розщепленими трансплантатами.

В одному випадку при пошкодженні нижньої кінцівки виконували пластику дефекту плоским ковзким клаптем, сформованим за допомогою тканинного експандера (об'єм 400 мл), 2 етапи.

У 6 випадках пошкодження верхньої кінцівки й залученням у зону пошкодження м'язів, су- хожилків для повноцінного відновлення функції використовували шкірно-жирові трубчасті клапті - 24 втручання, які доповнювалися в 5 випадках пластикою клаптями з місцевих тканин, в одному випадку для закриття дефекту використали плоский клапоть.

В одному випадку використання трубчатого клаптя спричинило його частковий некроз на етапі адаптації клаптя на рановій поверхні, що потребувало повторної реконструкції.

Як приклад, у хворого Г. з травматичним відокремленням кінцівки для формування повноцінної кукси - торакодорзальний шкірно-м'язовий клапоть на осьовому кровопостачанні (рис. 1).

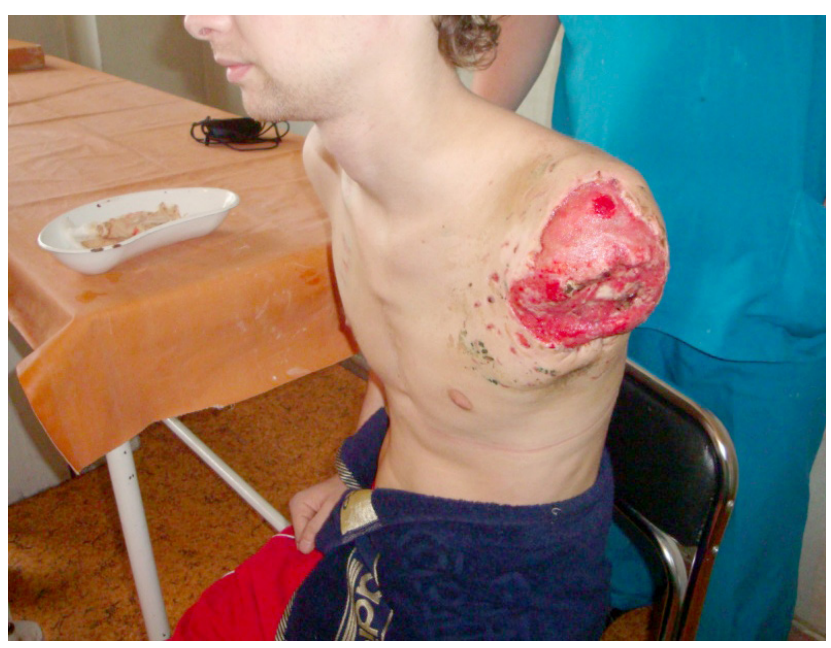

Рис. 1. Хворий Л., 23 роки. Травматичне відокремлення лівої верхньої кінцівки на рівні плечового суглоба.

При проведенні УЗДС візуалізували торакодорзальну артерію (кінцева гілка підлопаткової артерії) під гострим кутом проходить по латеральній стінці грудної клітини під широкий м'яз спини. Довжина позам'язової частини судини 80 мм, м'язова частина візуалізується протягом 50 мм (розпадається на гілки, вертикальна гілка діаметром 12 мм, діаметр в пригирловому сегменті 35 мм, дистальніше 20 мм ЛШК max $=39$ см/с, ЛШК $\min =3$ см/с, PI = 0,89 (рис. 2).

При проведенні дослідження виконували маркування клаптя (рис. 3).

Хворий був виписаний на 10-ту добу з повним приживленням клаптя (рис. 4).

Таким чином, детальне дослідження гемодинаміки в ділянці пошкодження, візуалізація живильних судин майбутніх складних клаптів, доцільність їх використання у кожному конкретному випадку з урахуванням ризиків можливих ускладнень дозволило отримати негативний результат лише у 2 \% випадків відновних оперативних втручань. 


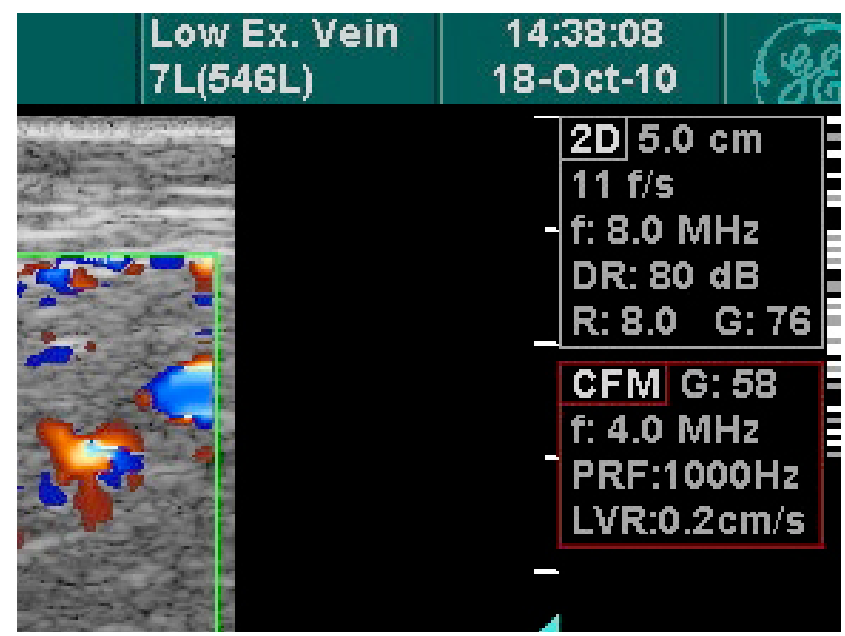

Рис. 2. Сканограма а. thoracodorsalis sinistra y peжимі КДК.

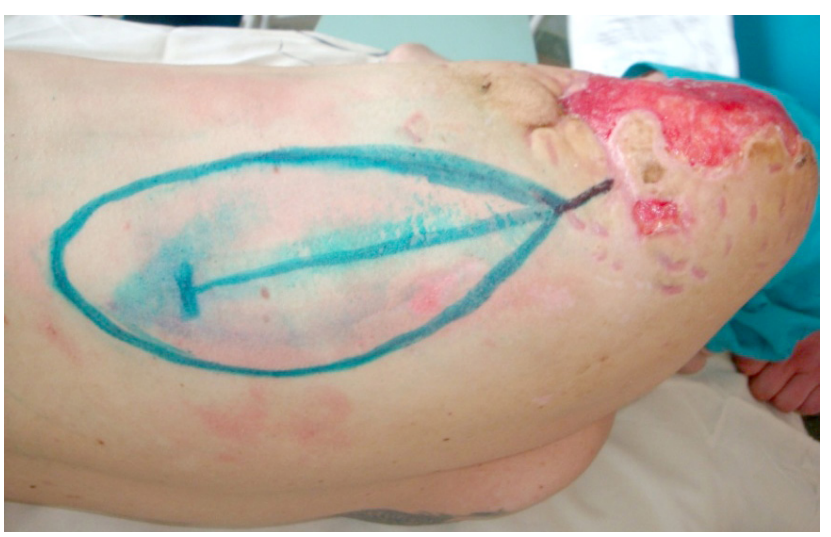

Рис. 3. Маркування складного комплексу тканин за допомогою УЗДС.

\section{СПИСОК ЛІТЕРАТУРИ}

1. Власова И. В. Ультразвуковая диагностика повреждений периферических артерий при закрытой травме. Клинические случаи / И. В. Власова // Случай из практики. - 2014. - № 4. - С. 57-73.

2. Паршикова С. А. Неинвазивные методы мониторинга раневого процесса (обзор литературы). Перспективы их применения в челюстно-лицевой хирургии у детей / С. А. Паршикова, В. В. Паршиков // Современные проблемы науки и образования. - 2012. - № 2. https://www.science-education.ru/ru/ article/view?id=5840.

3. Ультразвуковая диагностика течения репаративного процесса при оперативном лечении переломов костей голени / В. В. Писарев, А. В. Алейников, Э. В. Тихомолова, И. В. Васин // Вестник Ивановской медицинской академии. - 2013. T. 18, № 3. - С. 35-39.

4. Feng S. A prospective head-to-head comparison of color Doppler ultrasound and computed tomographic angiography in the preoperative planning of lower extremity perforator flaps / S. Feng, P. Min, L. Grassetti [et al.] // Plast. Reconstr. Surg. - 2016.

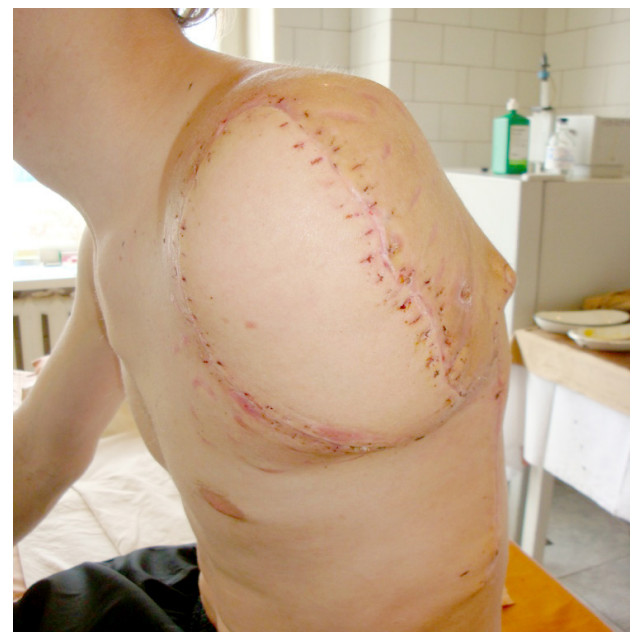

Рис. 4. Результат оперативного втручання із заміщення дефекту покривних тканин плечового суглоба (9-та доба).

Висновки. 1. Вибір способу реконструктивного втручання відносно травмованих покривних тканин залежав від розмірів, глибини та ступеня пошкодження кінцівок, при цьому об’єктивна оцінка кровообігу в кінцівці та регіональної гемодинаміки безпосередньо в ділянці пошкодження методом УЗДС дозволила достовірно прогнозувати можливість післяопераційних ускладнень у пацієнтів.

2. Використання методики УЗДС для вибору методу та об’єму реконструкції пошкодженої ділянки кінцівки з використанням складних комплексів тканин дозволило отримати позитивний результат у 98 \% випадків втручань.
- No. 137 (1). - P. 335-47. doi: 10.1097/PRS.0000000000001895. 5. Traumatic femoral artery thrombosis diagnosed by point-ofcare ultrasonography in the pediatric emergency department / S. D. Jones, J. Fischer, C. Kwan, M. Tessaro // Pediatr. Emerg Care. - 2016. - No. 32 (12). - P. 885-887.

6. Montorfano M. A. Point-of-care ultrasound and Doppler ultrasound evaluation of vascular injuries in penetrating and blunt trauma / M. A. Montorfano, F. Pla, L. Vera [et al.] // Crit. Ultrasound J. - 2017. - No. 9 (1). - P. 5. doi: 10.1186/s13089017-0060-5.

7. Montorfano M. A. The FAST D protocol: a simple method to rule out traumatic vascular injuries of the lower extremities / M. A. Montorfano, L. M. Montorfano, F. Perez Quirante [et al.] // Crit. Ultrasound J. - 2017. - No. 9 (1). - P. 8. doi: 10.1186/ s13089-017-0063-2.

8. Zhang C. Correlation between microcirculation and contrastenhanced ultrasonography after crush injury of limbs / C. Zhang, X. Wang, J. Tang // J. Med. Ultrason. - 2018. - No. 45 (2). P. 307-313. doi: 10.1007/s10396-017-0841-2. 


\section{REFERENCES}

1. Vlasova, I.V. (2014). Ultrazvukovaya diagnostika povrezhdeniy perifericheskikh arteriy pri zakrytoy travme. Klinicheskiye sluchai [Ultrasound of damage to peripheral arteries with closed trauma. Clinical cases]. Sluchai iz praktiki - Cases from Practice, 4, 57-73 [in Russian].

2. Parshikova, S.A., \& Parshikov, V.V. (2012). Neinvazivnyye metody monitoringa ranevogo protsessa (obzor literatury). Perspektivy ikh primeneniya $\mathrm{v}$ chelyustno-litsevoy khirurgii u detey [Non-invasive methods for monitoring the wound process (literature review). Prospects for their use in maxillofacial surgery of children]. Sovremennye problemy nauki i obrazovaniya - The Modern Problems of Science and Education, 2. doi.scienceeducation.ru/ru/article/view?id=5840 [in Russian].

3. Pisarev, V.V., Aleynikov, A.V., Tikhomolova, Ye.V., \& Vasin, I.V. (2013). Ultrazvukovaya diagnostika techeniya reparativnogo protsessa pri operativnom lechenii perelomov kostey goleni [Ultrasound of the course of the reparative process in the operative treatment of crural bone fractures]. Vestnik Ivanovskoy meditsinskoy akademii - Bulletin of the Ivanovo Medical Academy, 18 (3), 35-39 [in Russian].

4. Feng S., Min P., Grassetti L., Lazzeri D., Sadigh P., Nicoli F., . . . \& Zhang Y.X. (2016). A prospective head-to- head comparison of color doppler ultrasound and computed tomographic angiography in the preoperative planning of lower extremity perforator flaps. Plast. Reconstr. Surg., 137 (1), 335347. doi: 10.1097/PRS.0000000000001895.

5. Jones, S.D., Fischer, J., Kwan, C., \& Tessaro, M. (2016). Traumatic femoral artery thrombosis diagnosed by point-of-care ultrasonography in the pediatric emergency department. Pediatr. Emerg. Care., 32 (12), 885-887.

6. Montorfano, M.A., Pla, F., Vera, L., Cardillo, O., Nigra, S.G., \& Montorfano, L.M. (2017). Point-of-care ultrasound and Doppler ultrasound evaluation of vascular injuries in penetrating and blunt trauma. Crit. Ultrasound J., 9 (1), 5. doi: 10.1186/s13089-0170060-5.

7. Montorfano M.A., Montorfano L.M., Perez Quirante F., Rodríguez F., Vera L., \& Neri L. (2017). The FAST D protocol: a simple method to rule out traumatic vascular injuries of the lower extremities. Crit. Ultrasound J., 9 (1), 8. doi: 10.1186/s13089017-0063-2.

8. Zhang C., Wang X., Tang J. (2018). Correlation between microcirculation and contrast-enhanced ultrasonography after crush injury of limbs. J. Med. Ultrason., 45 (2), 307-313. doi: 10.1007/s10396-017-0841-2.

Отримано 25.06.2018

Електронна адреса для листування: alena.ponomarenko@gmail.com

\author{
E. V. PONOMARENKO, M. YU. GRIGORYEVA
}

Zaporizhzhia State Medical University

\title{
NON-INVASIVE METHODS OF DIAGNOSTICS IN THE PLANNING OF RECONSTRUCTIVE INTERVENTIONS AT THE LIMITS OF COMPLICATED COMPLEXES OF TISSUE
}

\begin{abstract}
The aim of the work: to investigate the effectiveness of the ultrasonic duplex scanning method in the planning of reconstructive interventions in the case of defects in the lining of the limbs with complicated tissue complexes.

Materials and Methods. Data of 50 patients who underwent ultrasound in the preoperative period to select the scope of surgery were analyzed. In the study of limb hemodynamics included confirmation of the patency of the vessels and the degree of their functioning. In addition, ultrasound were used to study regional hemodynamics in the area of the wound defect and in the donor region of the future complex flap.

Results and Discussion. In group I ( $\mathrm{n}=15)$, patients with extensive (more than $1 \%$ area) wound surface and soft tissue damage below the deep fascia after detailed preoperative preparation and hemodynamic investigation of the area of damage, 25 (20.2 \%) DPT recovery operations were performed. Group II $(n=13)$ consisted of victims with DFT who emerged together or as a result of damage to the joint-joint apparatus - 42 (33.9\%) of the intervention. Group III $(n=22)$, patients with combined or multiple trauma, accompanied by damage to the main vessels, nerves, partial or complete dissection of the limb. In this group, 57 (45.9 \%) reconstructions of DPT were performed.
\end{abstract}

Key words: flap; ultrasound; reconstructive interventions; damage area; limbs. 


\author{
Е. В. ПОНОМАРЕНКО, М. Ю. ГРИГОРЬЕВА
}

Запорожский государственный медицинский университет

\title{
НЕИНВАЗИВНЫЕ МЕТОДЫ ДИАГНОСТИКИ В П.ЛАНИРОВАНИИ РЕКОНСТРУКТИВНЫХ ВМЕШАТЕЛЬСТВ НА КОНЕЧНОСТЯХ С.ЛОЖНЫМИ КОМП.ЛЕКСАМИ ТКАНЕЙ
}

\begin{abstract}
Цель работы: исследовать эффективность метода ультразвукового дуплексного сканирования в планировании реконструктивных вмешательств при дефектах покровных тканей конечностей сложными комплексами тканей.

Материалы и методы. В работе проанализированы данные о 50 больных, которым в предоперационном периоде с целью выбора объема оперативного вмешательства выполняли ультразвуковое дуплексное сканирование (УзДС). В задачи исследования гемодинамики конечности входило подтверждение проходимости сосудов и степень их функционирования. Кроме того, УЗДС использовали для исследования регионарной гемодинамики в зоне раневого дефекта и в донорской области будущего сложного лоскута.

Результаты исследований и их обсуждение. В І группе ( $\mathrm{n}=15$ ) больным с обширной (более 1 \% площади) раневой поверхностью и повреждением мягких тканей ниже глубокой фасции после детальной предоперационной подготовки и исследования гемодинамики области повреждения выполнено 25 (20,2 \%) восстановительных операций ДПТ. II группа (n = 13) состояла из пострадавших с ДПТ, которые возникли вместе или в результате повреждения костно-суставного аппарата - 42 (33,9 \%) вмешательства. III группа (n = 22) больных с сочетанной или множественной травмой, сопровождающейся повреждением магистральных сосудов, нервов, частичным или полным отчленением конечности. В этой группе выполнено 57 (45,9%) реконструкций ДПТ.
\end{abstract}

Ключевые слова: лоскут; ультразвуковое дуплексное сканирование; реконструктивные вмешательства; область повреждения; конечности. 